\title{
Strategy for Strengthening of Music Industry in Indonesia: How is Rule Organization Commitment as a Variable Intervening
}

\author{
$1^{\text {st }}$ Sriyono \\ Faculty of Business \\ Law and Social Sciences \\ University of Muhammadiyah Sidoarjo \\ Sidoarjo, Indonesia \\ sriyono@umsida.ac.id \\ $4^{\text {th }}$ Dewi Komala \\ Faculty of Business \\ Law and Social Sciences \\ University of Muhammadiyah Sidoarjo \\ Sidoarjo, Indonesia
}

\author{
$2^{\text {nd }}$ Wisnu Panggah Setiyono \\ Faculty of Business \\ Law and Social Sciences \\ University of Muhammadiyah Sidoarjo \\ Sidoarjo, Indonesia \\ $5^{\text {th }}$ Maulidha Kurnia \\ Faculty of Business \\ Law and Social Sciences \\ University of Muhammadiyah Sidoarjo \\ Sidoarjo, Indonesia
}

\author{
$3^{\text {rd }}$ Sigit Hermawan \\ Faculty of Business \\ Law and Social Sciences \\ University of Muhammadiyah Sidoarjo \\ Sidoarjo, Indonesia
}

\begin{abstract}
Research on strengthening Industry Music in Indonesia has not been done much, even though the music industry has contributed a lot to the strengthening of creative industry organizations. For example, there has never been any strengthening through the role of organizational commitment as an intervening variable. As we know that the success of an organization is determined by the fulfillment of personal needs to always improve the performance of its employees, both through training and the availability of a supportive work environment, so this can lead to a sense of commitment to the organization. This study aims to examine the ability of organizational commitment variables as intervening variables to increase employee satisfaction if employees are satisfied it will improve performance. The methodology used in this study is to use a quantitative approach using techniques path analysis, the population used is all employees at the music equipment company. Based on the results of statistical analysis states that that job training can increase organizational commitment, the work environment can increase organizational commitment, job training influence increase work motivation, work environment affect increase work motivation, organizational commitment can increase work motivation, organizational commitment as a variable intervening gives an indirect effect which is lower than the direct effect on training on work motivation, as well as the effect of organizational commitment as a variable intervening on the work environment on work motivation. The overall results of the study can be stated that organizational commitment cannot be a variable intervening for training work towards work motivation.
\end{abstract}

Keywords-Music Industry, Organization Commitment, Intervening

\section{INTRODUCTION}

Many of the ways have been researched on ways to increase the motivation of the music industry employees, but most of the companies are using money-giving incentives. There have been many studies that employ ways to motivate employees in addition to money-giving, therefore this research is very important to know because the way to increase motivation does not use the grant of money.

Many of the ways have been researched on ways to increase the motivation of the music industry employees, but most of the companies are using money-giving incentives. There have been many studies that employ ways to motivate employees in addition to money-giving, therefore this research is very important to know because the way to increase motivation does not use the grant of money. [1]

Training as one of the efforts to improve the performance of human resources in the organization so that it is expected to provide changes in skills, knowledge, attitudes, and behavior, towards the desired work behavior [2].The working environment in an organization is also contributing to the increase in employee motivation, a supportive working environment can motivate employees to work delivering optimum performance. Also, it is based. [3]

In this research, a commitment was deliberately used as a variable intervening because the commitment is seen as an attitude as the mobilizer of the person's motivation in work. [4] Organizational commitment is the willingness of workers to help realize the objectives of an organization and loyalty to become a member of the Organization [5], employee motivation should be created best for the dedication, love, Discipline, and the moral work of the employee increases [6]. Motivation is also able to provide encouragement given by the leadership to the employees to increase the spirit of work 
TABLE I. TOTAL OUTGOING AND PERMANENT EMPLOYEE

\begin{tabular}{|c|c|c|}
\hline Year & In & Out \\
\hline 2014 & 62 & 21 \\
\hline 2015 & 37 & 15 \\
\hline 2016 & 49 & 16 \\
\hline 2017 & 14 & 18 \\
\hline 2018 & 45 & 9 \\
\hline
\end{tabular}

Sources: PT. Yamaha Musical Products Indonesia (2019)

Based on research [7], improving the performance of its workers is to give motivation, besides, motivation is done in a variety of good ways through, direct communication between superiors to subordinates, increased salary of employees and Provide a good environment between fellow employees.[8]

Because according to factors such as work training and work environment acquired and perceived by employees will affect whether the employee does the job. When the work training is obtained helps the employees to gain the necessary skills and knowledge, supported by a working environment around the employee that provides comfort when employees do their job [9] so that employees are more committed to work.

The organizational commitment has a positive role in the dissemination of training influence and work discipline to the employee's performance, as well as the organizational commitment that positively affects employees ' performance. The research by [10], which shows that the complete facilities and convenience of the employee's work environment will make employees committed to survive in the organization will be stronger. Organizational commitment is needed to support employees ' performance because of the commitment of the organization positively affect the motivation of work [11]

This research will focus on increasing motivation, why this is done because with increasing motivation will improve the company's performance. In addition to using training and improving the environment of good performance in increasing motivation also involved the organization's commitment as a variable intervening. Through this variable can accelerate the purpose of the company

\section{THEORY}

Improving the performance of its workers is to give motivation, besides, motivation is done in a variety of good ways through, direct communication between superiors to subordinates, increased salary of employees and Provide a good environment between fellow employees.[8]. Because according to factors such as work training and work environment acquired and perceived by employees will affect whether the employee does the job. When the work training is obtained helps the employees to gain the necessary skills and knowledge, supported by a working environment around the employee that provides comfort when employees do their job so that employees are more committed to work.

The organizational commitment has a positive role in the dissemination of training influence and work discipline to the employee's performance, as well as the organizational commitment that positively affects employees ' performance. The complete facilities and convenience of the employee's work environment will make employees committed to survive in the organization will be stronger. Organizational commitment is needed to support employees ' performance because of the commitment of the organization positively affect the motivation of work [11]

The research of [9] shows that the working environment has a positive effect on organizational commitments. This shows that the more complete the facility and the better the employee's work environment then the employee's commitment will be stronger. Currently, research [12], suggesting that affective commitment and normative commitments greatly affect the motivation of employees to attend work.

Based on research conducted by [13] the relationship between the Organization's commitment to motivation is positive, in addition to that the motivation to work properly on one's self will arise when there is an organizational commitment to an Organization as an effort to achieve the mutual purpose. A study shows that the most important factor in achieving job satisfaction is motivation. Employees will be increasingly excited about completing their work when the company can raise motivation, both internally and externally. [14] says that human resources management is instrumental in motivating employees by providing opportunities to participate in training, thereby changing the commitment of the employee's organization. According to [15], increased skills, knowledge, and employee abilities can affect their organizational commitments. Also, employees who expect the benefits of their participation in training will be more committed to their organization.

The purpose of this research is to know whether the organizational commitment can become an intervening variable in increasing employee motivation, this research is very important to do because this research provides Another perspective on how to increase employee motivation.

\section{RESEARCH METHODS}

\section{A. Type of research}

The type of research conducted is an approach that uses quantitative description analysis with explanatory research. Research is conducted by the survey method in data collection, namely using questionnaires and interviews.

The population used in this research is the permanent employee of PT Yamaha Musical Products Indonesia which amounted to 998 people. The sampling technique uses the formula, Slovin, with an accuracy of $90 \%$, with the following formula [16]

$\mathrm{N}=\frac{N}{1+N(e)^{2}}$

Note : $\mathrm{N}=$ Population

$$
\mathrm{e}=\text { error }
$$

$\mathrm{n}=$ Total of sampling

Sampling techniques carried out by probability sampling methods with stratified sampling approaches

B. Operational definition 
TABEL II. VARIABLE INDICATOR

\begin{tabular}{|c|c|c|c|}
\hline No & Variable & Indicator & $\begin{array}{l}\text { Measurement } \\
\text { Level }\end{array}$ \\
\hline \multirow[t]{3}{*}{1.} & \multirow{3}{*}{$\begin{array}{l}\text { Work Training (X1) } \\
\text { [34]; [35]; dan [36] }\end{array}$} & Systematic procedures & \multirow[t]{3}{*}{ Interval } \\
\hline & & Technical skills & \\
\hline & & Career development & \\
\hline \multirow[t]{3}{*}{2.} & \multirow{3}{*}{$\begin{array}{l}\text { Work } \\
\text { Environmental(X2) } \\
\text { [37]; [38] }\end{array}$} & $\begin{array}{l}\text { Facilities and } \\
\text { infrastructure }\end{array}$ & \multirow[t]{3}{*}{ Interval } \\
\hline & & Work Conditions & \\
\hline & & Employee Relationship & \\
\hline \multirow[t]{3}{*}{3.} & \multirow{3}{*}{$\begin{array}{l}\text { Organization } \\
\text { Commitment (Z) } \\
{[39] ;[36] ;[40]}\end{array}$} & Affective Commitment & \multirow[t]{3}{*}{ Interval } \\
\hline & & Sustainable commitmen & \\
\hline & & Normative commitment & \\
\hline \multirow[t]{3}{*}{4.} & \multirow[t]{3}{*}{$\begin{array}{l}\text { Motivation (Y) } \\
{[36] ;[40]}\end{array}$} & $\begin{array}{l}\text { Security and safety } \\
\text { Requirements }\end{array}$ & \multirow[t]{3}{*}{ Interval } \\
\hline & & Social needs & \\
\hline & & $\begin{array}{c}\text { Self-actualization } \\
\text { needs }\end{array}$ & \\
\hline
\end{tabular}

Analysis of the data used is path analysis. This analysis is utilized to know the pattern of relationships between variables. This method serves to gain a direct or indirect influence

C. Structure Equation Model

$\mathrm{Z}=\beta_{0}+\beta_{1} \mathrm{X}_{1}$ (Work training $)+\beta_{2} \mathrm{X}_{2}$ ( Work

Enviroment) $+\mathrm{e}_{1}$

$\mathrm{Y}=\gamma_{0}+\gamma_{1} \mathrm{X}_{1}$ (Work training) $+\gamma_{2} \mathrm{X}_{2}$ Work Environment+ $\gamma_{3} \mathrm{Z}$ (Organization Commitment) $+\mathrm{e}_{2}$

\section{RESULT}

Based on the results of the statistical test shows that all variables qualify for the validity and reusability test, therefore carried out the next data test according to the research needs

Based on the above calculations can be detailed results as follows:

TABLE III. RECAPITULATION OF REGRESSION ANALYSIS RESULTS

\begin{tabular}{|l|c|c|c|}
\hline \multicolumn{1}{|c|}{ Variable } & Direct influence & Indirect influence & Total influence \\
\hline $\mathrm{X} 1 \rightarrow \mathrm{Z}$ & 0,298 & 0 & 0,298 \\
\hline $\mathrm{X} 2 \rightarrow \mathrm{Z}$ & 0,434 & 0 & 0,434 \\
\hline $\mathrm{X} 1 \rightarrow \mathrm{Y}$ & 0,217 & 0 & 0,217 \\
\hline $\mathrm{X} 2 \rightarrow \mathrm{Y}$ & 0,446 & 0 & 0,446 \\
\hline $\mathrm{Z} \rightarrow \mathrm{Y}$ & 0,218 & 0 & 0,218 \\
\hline $\mathrm{X} 1 \rightarrow \mathrm{Z} \rightarrow \mathrm{Y}$ & 0,217 & 0,065 & 0,282 \\
\hline $\mathrm{X} 2 \rightarrow \mathrm{Z} \rightarrow \mathrm{Y}$ & 0,446 & 0,075 & 0,521 \\
\hline
\end{tabular}

Source: Processed primary Data, 2020

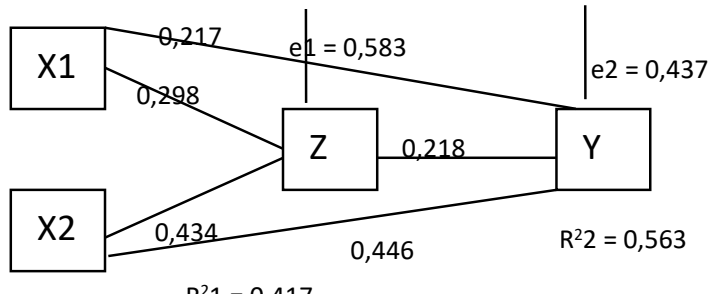

Fig. 1. Path Analysis

Variable analysis Intervening with Sobel Test

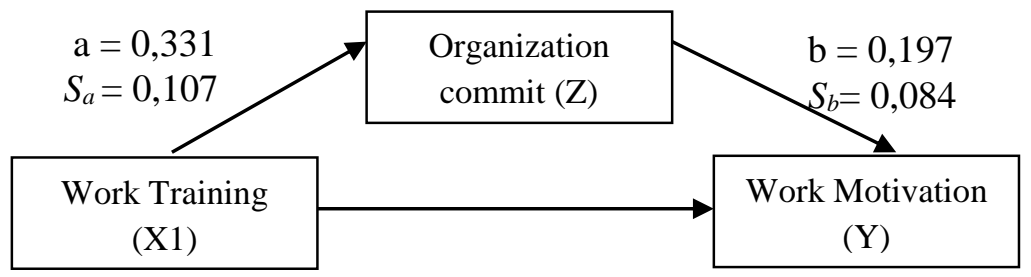

Fig. 2. Intervening $\mathrm{Z}$ analysis on variable $\mathrm{X} 1$ terhadap $\mathrm{Y}$ with Sobel Test

TABLE IV. SOBEL TEST 1

\begin{tabular}{|c|c|c|}
\hline Item & Sab & $\mathrm{t}$ \\
\hline Result & 0,036 & 1,811 \\
\hline
\end{tabular}

Based on the results of the calculations obtained $t$ research of Table 4.2 is $1.811<\mathrm{t}$ Table of 1.987 , then $\mathrm{H}_{1}$ rejected and $\mathrm{H}_{0}$ received. This suggests that the Organization's commitment ( $\mathrm{Z}$ ) as an intervening does not affect the working training relationship (X1) to the work motivation $(\mathrm{Y})$. 


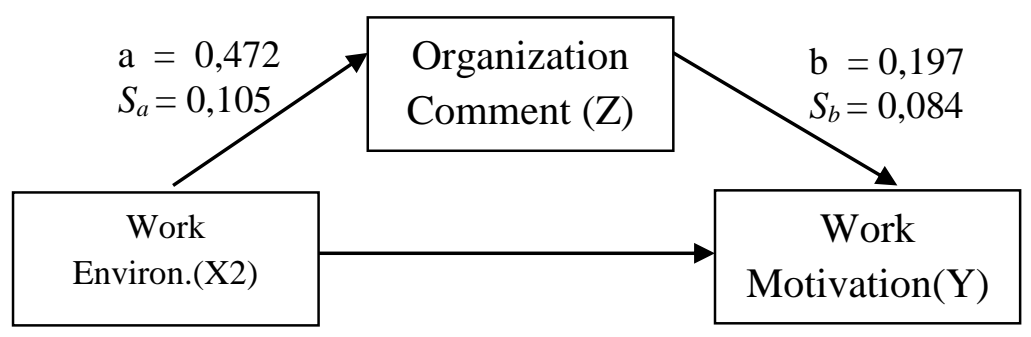

Fig. 3. Intervening $\mathrm{Z}$ analysis on variable $\mathrm{X} 2$ against $\mathrm{Y}$ with Sobel Test

TABLE V. SOBEL TEST 2

\begin{tabular}{|c|c|c|}
\hline TABLE V. SOBEL TEST 2 \\
\hline Item & Sab & $\mathrm{t}$ \\
\hline Result & 0,045 & 2,066 \\
\hline
\end{tabular}

Based on the results of the calculations obtained t research of Table 4.3 is $2.066>t$ Table of 1.987 , then H0 rejected and H5 received. This suggests that organizational commitment $(\mathrm{Z})$ as an intervening affects the working environment (X2) to work motivation (Y).

Variable regression analysis Intervening with causal Step method [32]

1. Organizational commitment $(\mathrm{Z})$ as an intervening variable on the work environment $(\mathrm{X} 2)$ on the work motivation (Y)

TABLE VI. TABLE OF REGRESSION ANALYSIS RESULTS IN X2 AGAINST Y

\begin{tabular}{|c|c|c|c|c|c|c|}
\hline \multicolumn{7}{|c|}{ Coefficients } \\
\hline & & \multicolumn{2}{|c|}{ Unstandardized Coefficients } & $\begin{array}{l}\text { Standardized } \\
\text { Coefficients }\end{array}$ & \multirow[b]{2}{*}{$\mathrm{t}$} & \multirow[b]{2}{*}{ Sig. } \\
\hline \multicolumn{2}{|c|}{ Model } & \begin{tabular}{|l|l}
$\mathrm{B}$ & \\
\end{tabular} & \begin{tabular}{l|l} 
Std. Error & \\
\end{tabular} & Beta & & \\
\hline \multirow[t]{2}{*}{1} & (Constant) & 6,719 & 1,468 & & 4,575 &, 000 \\
\hline & $\mathrm{X} 2$ & ,682 &, 075 & ,692 & 9,051 &, 000 \\
\hline
\end{tabular}

Source: Processed primary Data, 20

2. Equation of work environment regression (X2) against organizational commitment (Z). TABLE VII. TABLE OF REGRESSION ANALYSIS RESULTS X2 AGAINST Z

\begin{tabular}{|c|c|c|c|c|c|c|}
\hline \multicolumn{7}{|c|}{ Coefficients } \\
\hline & & \multicolumn{2}{|c|}{ Unstandardized Coefficients } & $\begin{array}{c}\text { Standardized } \\
\text { Coefficients }\end{array}$ & \multirow[b]{2}{*}{$\mathrm{t}$} & \multirow[b]{2}{*}{ Sig. } \\
\hline \multicolumn{2}{|c|}{ Model } & \begin{tabular}{|l|l}
$\mathrm{B}$ & \\
\end{tabular} & Std. Error & Beta & & \\
\hline \multirow[t]{2}{*}{1} & (Constant) & 9,417 & 1,806 & & 5,214 &, 000 \\
\hline & $\mathrm{X} 2$ & ,647 & ,093 & ,595 & 6,978 &, 000 \\
\hline
\end{tabular}

3. Equation of work environment regression (X2) and organizational commitment (Z) to the motivation of work (Y). TABLE VIII. TABLE OF REGRESSION ANALYSISTABLE

\begin{tabular}{|c|c|c|c|c|c|c|}
\hline \multicolumn{7}{|c|}{ Coefficients } \\
\hline & & \multicolumn{2}{|c|}{ Unstandardized Coefficients } & $\begin{array}{l}\text { Standardized } \\
\text { Coefficients }\end{array}$ & \multirow[b]{2}{*}{$\mathrm{t}$} & \multirow[b]{2}{*}{ Sig. } \\
\hline \multicolumn{2}{|c|}{ Model } & \begin{tabular}{|l|l}
$\mathrm{B}$ & \\
\end{tabular} & Std. Error & Beta & & \\
\hline \multirow[t]{3}{*}{1} & (Constant) & 4,254 & 1,597 & & 2,663 &, 009 \\
\hline & $\mathrm{X} 2$ & ,513 & ,089 & ,521 & 5,746 &, 000 \\
\hline & $\mathrm{Z}$ & ,262 & ,082 & ,289 & 3,190 & ,002 \\
\hline
\end{tabular}

Source: Processed primary Data, 2019

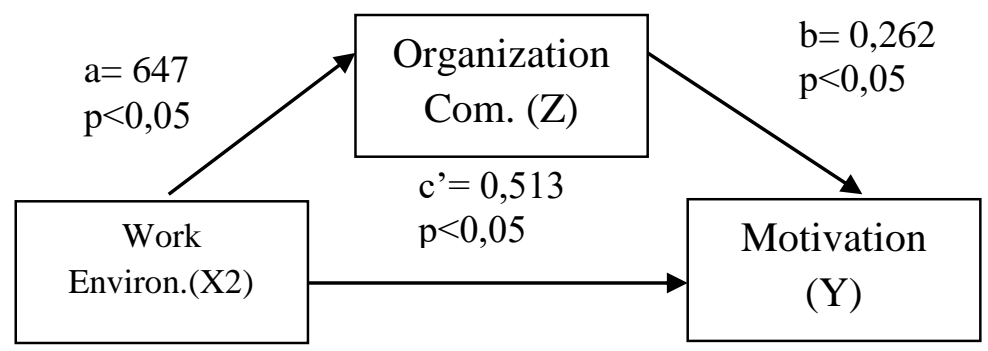

Fig. 4. Regression analysis of $\mathrm{X} 2$ against $\mathrm{Y}$ with intervening variables 


\section{DISCUSSION}

A. Influence of work training on motivation to work with organizational commitments as an intervening variable

Based on Table 4.1 the results the study showed under the training of significant influential work significantly greater than the indirect influence on the motivation of work with the commitment of the organization as an intervening variable. And after the Sobel test ( Table 4.2 and Table 4.3), the organization's commitment has no influence as the intervening variable on the training variables to the motivation of work.

It is defined by [17] with the statement that employees will be motivated by salary and other additional income so that they will work earnestly and eagerly on a given task. Also, the organizational commitment to employees will be high if the organization also meets their expectations so that it will also improve performance. At the research of [18], shows that motivation for learning, access training, and frequency of training against a continued commitment resulted in an insignificant relationship but against affective commitment and normative commitments Have a significant relationship.

Based on the research of [19], there is a positive role in the Organization's commitment to the effect of training and work discipline on performance as well as the positive influence of the Organization's commitment to employee performance. According to [21], organizational commitments can be assessed from the feelings of having on the organization. Such feelings can be created when there is employee involvement in various organizational activities, such as seeking advice from team members within the company, listening to employee issues and increasing engagement in the retrieval process Organizational decisions to a certain extent [22]. So in such a way employees will feel the participation and appreciated in the organization. Also, to maintain employees in the organization, leaders must provide a working environment with facilitative and enjoyable and supportive of them. And also provides training programs about self-preparedness and skills to enhance the personality characteristics of employees [23]

B. Environmental impact of work motivation with organizational commitment as an intervening

Based on Table 4.1, results in the work showed that the working environment significantly outweighs its indirect influence on the motivation of work with the Organization's commitment as an intervening variable. When conducted the Sobel test (Table 4.4 and Table 4.5, Table 4.6), the organizational commitment affects the working environment of work motivation as an intervening variable. And based on the causal step method, the organizational commitments can impartially

The working environment affects employee decisions to maintain membership in the organization. It is therefore very important to know the needs of employees so that they become committed. Based on (24), it explains that employees are happy to work on organizations that provide a positive working environment. Also according to [25], explaining that changes in office design can affect employee commitment. Also based on the research of [26], performance is the result of work motivation and employee ability as well as how employees adjust themselves to the constraints that occur in the vicinity. So if these constraints are ignored it will decrease the employee's performance. Such constraints are such as noise, office furniture, ventilation, and light. Therefore, to increase the motivation of working employees, leaders are also concerned about the constraints of the work environment, so that employees will be motivated and performance increased. The circumstances of the working environment can be said to be worthy or good when employees can do their work safely, healthy, optimally, and comfortably. A suitable working environment in the long term can be seen.[27] If the environment is poor, an organization will need more labor and time and not acquire an efficient system of work. An effective working environment is an environment where the achievement of the outcomes expected by the management [28]

In the study expressed by [29], said the same thing about the theory of motivation, that to create motivation to employees is to make a kind of bond between leaders with employees. One of the ways that leaders do is to adapt the situation of the working environment to today's modern era so that in this way the working environment will have a positive effect on the motivation of work.

According to [30] the commitment to stay in a career in an organization has no statistically significant effect on motivation to move. Motivation to remain in the work does not happen because of the commitment of the organization that employees have, but because of the factors that are profitable in the work environment. This can be indicated for the low implementation of HR management, such as attention and career development plans to employees who are still low, misperception of employees on promotion and performance, as well as ineffective performance appraisal.

Based [31], stated in his research that external factors such as socio-economic limitations and internal factors such as the lack of attention from the organization of its employees affect the work commitment of employees. The right human relationship between employees or with other authorities in any organization can build mutual trust and willingness to carry out a task with enthusiasm and delight [32].

When work training is done to help employees to acquire the necessary skills and knowledge, supported by a working environment around the employee that provides comfort when employees do their job, it will make Employees feel satisfied and motivated by their work [32]because employees are able to perform the work and arise strong commitment from employees to work properly and properly. Employees will be committed when they consider the organization offering opportunities for employees to learn and develop [24]

\section{CONCLUSION}

An effective step to improve employee motivation is to improve the hygiene of the work environment. To achieve maximum results, companies should often socialize the need for an employee to have an organizational commitment. Clean working environment and supported by high organization commitment will increase employee motivation. 


\section{REFERENCES}

[1] Anyim, C. F., Chidi, O. C., \& Badejo, A. E. (2012). Motivation and Employees' Performance in the Public and Private Sectors in Nigeria. International Journal of Business Administration, 3(1), $31-40$

[2] Rosianti, W., Susilo, H., dan Hakam, M. S. (2014). Upaya Dinas Koperasi UKM Dalam Menyelenggarakan Pendidikan dan Pelatihan Kewirausahaan untuk Meningkatkan Motivasi Berwirausaha. Jurnal Administrasi Bisnis, 12 (1), 1-8.

[3] Basuki, K., \& Maesaroh, M. (2017). Motivasi Sebagai Pemediasi Pengaruh Komitmen Dan Lingkungan Kerja Pada Kepuasan Kerja. Business Management Journal, 13(1), 1-15.

[4] Farida, S. I., Iqbal, M., Kurniasih, A. (2016). Pengaruh Kepercayaan Dan Komitmen Organisasi Terhadap Motivasi Dan Kepuasan Kerja. Jurnal Kependidikan, 46 (1), 121-134.

[5] Robbins, S. P. and Judge, T. A. (2011). Organizational Behavior $14^{\text {th }}$ edition. New Jersey : Prentice Hall

[6] Young, W., Davis, M., McNeill, I. M., Malhotra, B., Russell, S., Unsworth, K., \& Clegg, C. W. (2015). Changing Behaviour: Successful Environmental Programmes in the Workplace. Business Strategy and the Environment, 24(8), 689-703

[7] Raharjo, R.P. (2014). Pengaruh Pelatihan Terhadap Motivasi Kerja Dan Kinerja Pegawai (Studi Pada Pegawai Balai Besar Pelatihan Pertanian (BBPP) Ketindan-Lawang). Jurnal Administrasi Bisnis S1 Universitas Brawijaya, 15(2), 1-10.

[8] Darmawan, Y. Y., Supartha, W. G., dan Rahyuda, A. G. (2017). Pengaruh Pelatihan Terhadap Motivasi Kerja dan Kinerja di Prama Sanur Beach Bali. E-Jurnal Ekonomi dan Bisnis Universitas Udayana 6 (3), 1265-1290.

[9] Citraningtyas, Nuridha; Djastuti, I. (2017). Pengaruh Pelatihan dan Lingkungan Kerja Terhadap Kinerja Karyawan Dengan Kepuasan Kerja Sebagai Variabel Intervening (Studi Pada Karyawan Hotel Megaland Solo). Journal Of Management, 6(4), 1-11

[10] Abidin, M. I. Z., Pangtuluran, Y., \& Maria, S. (2016). Pengaruh Kepuasan Kerja, Lingkungan Kerja Dan Efikasi Diri Terhdapa Komitmen Organisasi Di Rumah Sakit Smc Samarinda. Jurnal Ekonomi Dan Keuangan, 13(1), 1-10.

[11] ] Hadiwijaya, H., \& Hanafi, A. (2013). Effect Of Culture And Organization Commitment To Employee Employment Motivation (Study On PT Astra International, Tbk - Honda Sales Operation Kanwil Palembang). Jurnal Ilmiah Manajemen Bisnis Dan Terapan, 1(2), 65-19

[12] Burton, J. P., Lee, T. W., \& Holtom, B. C. (2002). The Influence Of Motivation To Attend, Ability To Attend, And Organizational Commitment On Different Types Of Absence Behaviors. Journal of Managerial Issues, 14(2), 181-197.

[13] Abdullah. (2014). Pengaruh Komitmen Terhadap Kepuasan Kerja Auditor: Motivasi Sebagai Variabel Intervening. Jurnal Akuntansi, 2 (1), 9-23.

[14] Bulut, C., \& Culha, O. (2010). The effects of organizational training on organizational commitment. International Journal of Training and Development, 14(4), 309-322.

[15] Kumar, P. Kishore \& Vikram, V. (2017). A Study on Motivation for Training, Job Satisfaction, Affective Commitment and Continuance Commitment. Scholars Journal of Economic, Business and Management, 4 (10), 709-712

[16] Hermawan, Sigit dan Amirullah. (2016). Metodologi Penelitian Bisnis Pendekatan Kuantitatif dan Kualitatif. Media Nusa Creative : Malang.

[17] Tone, K. (2018). Examining the Moderating Effect of Work Motivation on the Lecturer Performance: A Contribution to Organizational Commitment and Competence. Research in Business and Management, 5(2), 1-16

[18] Nugraha, R. S., Setiawan, M., dan Puspaningrum, A. (2017). Komitmen Organisasional Sebagai Mediasi Pengaruh Pelatihan Dan Disiplin Kerja Terhadap Kinerja Pegawai. Jurnal Bisnis dan Manajemen, 4 (1), 55-63.

[19] Wadhwa, D. S. and Verghese, M. (2015). Impact of Employee Empowerment On Job Satisfaction and Organizational
Commitment: An Empirical Investigation with Special Reference to Selected Cement Industry in Chhattisgarh. International Journal in Management and Social Science, 3(3), 280-286.

[20] Hanaysha, J. (2016). Examining the Effects of Employee Empowerment, Teamwork, and Employee Training on Organizational Commitment. Procedia - Social and Behavioral Sciences, 229, 298-306.

[21] Danish, R. Q., Ramzan, S., \& Ahmad, F. (2013). Effect of Perceived Organizational Support and Work Environment on Organizational Commitment; Mediating Role of Self-Monitoring. Advances in Economics and Business, 1(4), 312-317.

[22] Amdan, S., Rahman, R. A., Shahid, S. A. M., Bakar, S. A., Khir, M. M., \& Demong, N. A. R. (2016). The Role of Extrinsic Motivation on the Relationship between Office Environment and Organisational Commitment. Procedia Economics and Finance, 37(16), 164-169.

[23] Morrow, P. C., McElroy, J. C., \& Scheibe, K. P. (2012). Influencing organizational commitment through office redesign. Journal of Vocational Behavior, 81(1), 99-111

[24] Al-Omari, K., \& Okasheh, H. (2017). The influence of work environment on job performance: A case study of engineering company in Jordan. International Journal of Applied Engineering Research, 12(24), 15544-15550.

[25] Porter, T. H., Riesenmy, K. D., \& Fields, D. (2016). Work environment and employee motivation to lead. American Journal of Business, 31(2), 66-84.

[26] Wardani, Yuniatin Trisnawati dan Awatara, I Gusti Putu Diva. (2019). Performance Analysis Ofa State Elementary School Headmaster Through Training and Work Envrionment With Motivation As Intervening. Trikonomika, 18 (1), 25-29.

[27] Korzynski, P. (2013). Employee motivation in new working environment. International Journal of Academic Research, 5(5), 184-188.

[28] Tharanganie, M. G. (2013). The Influence of Career Commitment on Motivation to Learn and Motivation to Transfer. Asian Journal of Business and Management, 01(03), 78-86.

[29] Muwagga, A. M., \& Genza, M. G. (2011). The dilemma of teacher professionalism and commitment in Roman Catholic founded secondary schools in Uganda. Educational Research, 2(1), 730735 .

[30] Munawaroh., Yuniarti, Desi., dan Hayati, Memi Nor. (2015). Analisis Regresi Variabel Mediasi dengan Metode Kausal Step. Jurnal Eksponensial, 6 (2), 193-199

[31] Mohammadtaheri, N. (2011). The study of effective factors on the teachers' work commitment in High Schools. Procedia - Social and Behavioral Sciences, 29(Iceepsy), 1524-1530.

[32] Arifin, M. Fachrul. (2017). Pengaruh Pengembangan Karir, Penempatan Kerja dan Pelatihan Terhadap Prestasi Kerja Karyawan Pada UD. Paving SAS Tulangan Sidoarjo. Program Studi Manajemen. Universitas Muhammadiyah Sidoarjo.

[33] Rachmawati, Riska. (2015). Pengaruh Budaya Organisasi Dan Diklat Terhadap Kinerja Karyawan di Koperasi Simpan Pinjam Sindhu Arta Pusat di Sidoarjo. Program Studi Manajemen SDM, Universitas Muhammadiyah Sidoarjo

[34] Moeheriono. (2014). Perencanaan, Aplikasi, dan Pengembangan Indikator Kinerja Utama Bisnis dan Publik. Jakarta: Rajawali Press.

[35] Elydar, Lilik Isna. (2017). Pengaruh Kepuasan Kerja dan Lingkungan Kerja Terhadap Komitmen Organisasi dan Kinerja Karyawan di Rumah Sakit Islam Siti Hajar Sidoarjo. Program Pascasarjana Manajemen. Universitas Muhammdiyah Sidoarjo

[36] Najich, Abdulloh. (2017). Pengaruh Kompensasi, Motivasi dan Lingkungan Kerja Terhadap Kinerja Dokter di RSUD PattiaSampang Kabupaten Sampang. Program Pascasarjana. Universitas Muhammadiyah Sidoarjo.

[37] Trisnaningsih, Sri. (2001). Pengaruh Komitmen Terhadap Kepuasan Kerja Auditor : Motivasi Sebagai Variabel Intervening. Tesis. Program Studi Magister Akuntansi Universitas Diponegoro

[38] Supriyanto, Achmad Sani dan Maharani, Vivin. (2013). Metodologi Penelitian Manajemen Sumberdaya Manusia. Malang: UIN Maliki Press. 